\title{
Removal of Microcystis aeruginosa cells using the dead cells of a marine filamentous bacterium, Aureispira sp. CCB-QB1
}

\author{
Go Furusawa ${ }^{\text {Corresp., } 1}$, Koji Iwamoto ${ }^{2}$ \\ ${ }^{1}$ Centre for Chemical Biology, Universiti Sains Malaysia, Bayan Lepas, Penang, Malaysia \\ 2 Malaysia-Japan International Institute of Technology, Kuala Lumpur, Wilayah Persekutuan Kuala Lumpur, Malaysia \\ Corresponding Author: Go Furusawa \\ Email address: furusawa@usm.my
}

Abstract Inorganic and synthetic flocculants are widely investigated for removing harmful microalgae, such as Microcystis aeruginosa. However, their toxicity and nonbiodegradability are shortcomings. Bioflocculants based on extracellular polysaccharides have attracted much attention as alternative flocculants. However, its high production cost is a limiting factor for applying bioflocculants. Here, we investigate the potential of the dead cells of a marine filamentous bacterium, Aureispira sp. CCB-QB1, as a novel flocculant on $M$. aeruginosa cells. The removal efficiency of $M$. aeruginosa cells by the dead cells was measured by mixing and shaking both components in a buffer with $5 \mathrm{mM}$ $\mathrm{CaCl}_{2}$ in different incubation times and concentrations of the dead cells. After that, the minimum effective concentration of $\mathrm{CaCl}_{2}$ was determined. The combination effect of $\mathrm{FeCl}_{3}$ and the dead cells on the removal efficiency was tested. The structure of cell aggregates consisted of the dead cells and $M$. aeruginosa cells were also observed using a scanning electron microscope. The maximum removal efficiency $(75.39 \%)$ was reached within 3 min in the presence of $\mathrm{CaCl}_{2}$ when $5 \mathrm{mg} / \mathrm{ml}$ of the dead cells (wet cells) were added. The optimal concentration of $\mathrm{CaCl}_{2}$ was $5 \mathrm{mM}$. The combination of the dead cells and a low concentration of $\mathrm{FeCl}_{3}(10 \mathrm{mg} / \mathrm{L})$ with $5 \mathrm{mM}$ of $\mathrm{CaCl}_{2}$ significantly improved the removal efficiency by about 1.2 times $(P<0.05)$. This result indicates that the combination usage of the dead cells can reduce the use of $\mathrm{FeCl}_{3}$. These results indicated that the dead cells could potentially be a novel biolfocculant to remove $M$. aeruginosa cells. 
1 Removal of Microcystis aeruginosa cells using the dead cells of a marine filamentous

2 bacterium, Aureispira sp. CCB-QB1

3

4 Go Furusawa ${ }^{1, *}$, Koji Iwamoto ${ }^{2}$

5 Author's institutional affiliation:

$6 \quad{ }^{1}$ Centre for Chemical Biology, Universiti Sains Malaysia, 10 Persiaran Bukit Jambul, 11900

$7 \quad$ Bayan Lepas, Penang, Malaysia

$8{ }^{2}$ Malaysia-Japan International Institute of Technology (MJIIT), Universiti Teknologi

9 Malaysia, Jalan Sultan Yahya Petra, 54100 Kuala Lumpur, Malaysia.

10

11 Contact information;

12 Go Furusawa

13 Centre for Chemical Biology, Universiti Sains Malaysia, 10 Persiaran Bukit Jambul, 11900

14 Bayan Lepas, Penang, Malaysia

15 E-mail: furusawa@usm.edu.my

16

17 


\section{Abstract}

Inorganic and synthetic flocculants are widely investigated for removing harmful microalgae, such as Microcystis aeruginosa. However, their toxicity and non-biodegradability are shortcomings. Bioflocculants based on extracellular polysaccharides have attracted much attention as alternative flocculants. However, its high production cost is a limiting factor for applying bioflocculants. Here, we investigate the potential of the dead cells of a marine filamentous bacterium, Aureispira sp. CCB-QB1, as a novel flocculant on M. aeruginosa cells. The removal efficiency of $M$. aeruginosa cells by the dead cells was measured by mixing and shaking both components in a buffer with $5 \mathrm{mM} \mathrm{CaCl}_{2}$ in different incubation times and concentrations of the dead cells. After that, the minimum effective concentration of $\mathrm{CaCl}_{2}$ was determined. The combination effect of $\mathrm{FeCl}_{3}$ and the dead cells on the removal efficiency was tested. The structure of cell aggregates consisted of the dead cells and $M$. aeruginosa cells were also observed using a scanning electron microscope. The maximum removal efficiency $(75.39 \%)$ was reached within 3 min in the presence of $\mathrm{CaCl}_{2}$ when $5 \mathrm{mg} / \mathrm{ml}$ of the dead cells (wet cells) were added. The optimal concentration of $\mathrm{CaCl}_{2}$ was $5 \mathrm{mM}$. The combination of the dead cells and a low concentration of $\mathrm{FeCl}_{3}(10 \mathrm{mg} / \mathrm{L})$ with $5 \mathrm{mM}$ of $\mathrm{CaCl}_{2}$ significantly improved the removal efficiency by about 1.2 times $(P<0.05)$. This result indicates that the combination usage of the dead cells can reduce the use of $\mathrm{FeCl}_{3}$. These results indicated that the dead cells could potentially be a novel biolfocculant to remove $M$. aeruginosa cells.

\section{Introduction}

Harmful bloom of cyanobacteria (cyanoHABs) by toxic cyanobacterial species have been recognized in many countries (Briand et al., 2003) and generate direct economic damages because of the pollution of freshwater environments, as sources of drinking water, agriculture, fishing, and industry water (Hamilton, Salmaso \& Paerl, 2016). CyanoHABs also seriously affect health problems in humans and animals because of the production of toxins such as microcystin and anatoxin (Azevedo et al., 2002; Katırcıoğlu, Akin \& Atici, 2004). For instance, microcystin and 
56 its derivatives disrupt the structure and function of the liver and cause deaths by liver hemorrhage

57 (Azevedo et al., 2002: Katırcıoğlu, Akin \& Atici, 2004). CyanoHABs occur in many countries in

tropical and temperate regions. In addition, it is known that climate change, such as rising $\mathrm{CO}_{2}$ and global warming, is likely to stimulate the development of harmful cyanobacterial blooms in eutrophic waters (Visser et al., 2016).

To remove microalgae, including cyanobacteria cells, from the water column, several types of flocculants are used. The flocculants are mainly classified into three groups, such as inorganic flocculants (e.g., polyaluminum chloride (PAC) and ferric chloride $\left(\mathrm{FeCl}_{3}\right)$ ), organic synthetic flocculants (e.g., polyacrylamide derivatives), and some kinds of clay or bioflocculants mainly consisting of polysaccharides produced by microorganisms (Salehizadeh \& Shojaosadati, 2001). Inorganic flocculants, such as $\mathrm{PAC}$ and $\mathrm{FeCl}_{3}$, were low-cost materials and exhibited a high removal efficiency on M. aeruginosa cells (Li et al., 2015: Sun et al., 2012; Zhang et al., 2011). However, a high dosage of the flocculants is required for its high removal efficiency. In addition, the sludge containing inorganic flocculants consisted of heavy metals is toxic to the environment (Fast, Kokabian \& Gude, 2014). Especially, aluminum may be one of the risk factors for Alzheimer's disease (Flaten, 2001; Fast, Kokabian \& Gude, 2014).

Polyacrylamide derivatives are extensively used to treat natural water and sewage because of their high removal efficiency on pollutants (Kurenkov, Hartan \& Lobanov, 2002). Polyacrylamide derivatives are also used in removing microalgae, including $M$. aeruginosa (Pugazhendhi et al., 2019; Cai et al., 2021). However, acrylamide is considered a probable human carcinogen and mutagen in vitro and in vivo experiments using animals (Dearfield et al., 1988; Dearfield et al., 1995). Thus, there are concerns about their toxicity and less biodegradability.

To date, bioflocculants, which are non-toxic and biodegradable compounds, have attracted attention as an alternative to chemical flocculants. Bioflocculants are biological polymers, mainly extracellular polysaccharides (EPS) or proteins, produced by living organisms, particularly plants and microbes. As the plant-based natural coagulants, some seeds and fruit/ peels, such as Cicer aretinum, Moringa oleifera, cactus, are reported (Kumar, Othman \& Asharuddin, 2017). Bioflocculants composed of EPS produced by bacteria belonging to genera Bacillus (Deng et al., 2003; Zheng et al., 2008), Corynebacterium (He, Li \& Chen, 2004), Klebsiella (Wang et al., 2007), Paenibacillus (Li et al., 2013), Proteus (Xia et al., 2008) and Pseudomonas (Azzam \& Tawfik, 2015; Liu et al., 2016) were also found during past decades. These bioflocculants were exhibited 
87 high removal efficiency $(80-99.6 \%)$ on negatively charged clay particles, kaolin. In addition, several investigations demonstrated that the bioflocculants were helpful for removing $M$. aeruginosa. For instance, Sun and colleagues reported that bioflocculant, EPS-1, produced by Bacillus amyloliquefaciens could remove approximately $88 \%$ of $M$. aeruginosa cells (Sun et al., 2015a). Bioflocculant produced by Pseudomonas aeruginosa ZJU1 combined with kaolin, $\mathrm{CaCl}_{2}$, and $\mathrm{KAI}\left(\mathrm{SO}_{4}\right)_{2}$ also exhibited high removal efficiency on M. aeruginosa cells (Sun et al., 2015b). The investigation conducted by Zhang et al. demonstrated that the bioflocculant produced by Halobacillus sp. strain H9 also successfully removed M. aeruginosa cells (Zhang et al., 2019). Besides plants and microbes, another type of polysaccharide, chitosan, produced from shells of crustaceans has also attracted much attention as a bioflocculant to remove $M$. aeruginosa. The study conducted by Park et al. demonstrated that chitosan fiber removed almost $89 \%$ of $M$. aeruginosa cells (Park et al., 2020). Ma and colleagues also reported that chitosan-aluminum chloride combined coagulants exhibited a high removal efficiency ( $>90 \%)$ on M. aeruginosa cells (Ma et al., 2016). Thus, bioflocculants consisted of non-toxic and biodegradable biopolymers might be useful for removing $M$. aeruginosa cells. However, the high cost of the natural macromolecules, especially EPS from microorganisms, limits their application.

In a previous investigation, we reported that a marine filamentous bacterium, Aureispira sp. $\mathrm{CCB}-\mathrm{QB} 1$, formed cell aggregates in the presence of $\mathrm{CaCl}_{2}$ (Furusawa, Hartzell \& Navaratnam, 2015). In addition, the dead cells of Aureispira sp. CCB-QB1, which has negatively charged cell surface, could absorb negatively charged clay particles, kaolin, and form aggregates with kaolin particles in the presence of $\mathrm{CaCl}_{2}$ (Hasyimah, Furusawa \& Amirul, 2020). Our investigation demonstrated that the precipitation might be occurred by neutralizing the negative charge of both kaolin and the dead cells by adding a divalent cation, $\mathrm{CaCl}_{2}$. Based on the result, we predicted that M. aeruginosa cells might also be precipitated by the dead cells in the presence of $\mathrm{CaCl}_{2}$ (Hasyimah, Furusawa \& Amirul, 2020). Furthermore, the preparation of the dead cells was more straightforward than that of known bioflocculants consisted of polysaccharides, because the precipitation and purification steps required in known bioflocculants were not necessary to prepare the dead cells. This information indicates that the dead cells have the potential for an inexpensive flocculant compared with the other bioflocculants based on extracellular polymers. In this study, to confirm our prediction, we performed to remove $M$. aeruginosa cells by using the dead cells 
117 from aqueous samples under various conditions. To the best of our knowledge, this is the first

118 report to remove the M.aeruginosa using the dead cells of a filamentous bacterium.

119

120

121

122

123

124

125

126

127

128

129

130

131

132

133

134

135

136

137

138

139

140

141

142

143

144

145

146

\section{Materials and Methods}

\section{Microorganisms and culture conditions}

Aureispira sp. CCB-QB1 (referred to hereafter as CCB-QB1) deposited in CCB Microbial Biodiversity Library (CCB-MBL) (No. CCB-MBL0192) were the cells used as a bioflocculant in this study. The cells were cultured in a modified high nutrient artificial seawater medium $(\mathrm{H}-$ ASWM) (0.91 \% tryptones, $3.39 \%$ artificial sea salt, $10 \mathrm{mM}$ 4-(2-hydroxyethyl)-1piperazineethanesulfonic acid (HEPES), $\mathrm{pH}$ 7.6) described by Hasyimah et al. (Hasyimah, Furusawa \& Amirul) at $30^{\circ} \mathrm{C}$ for $20 \mathrm{~h}$ with shaking (200 rpm). Microcystis aeruginosa NISE 102 strain (referred to hereafter as NISE 102) (Gao, Shimizu \& Xue, 2012) was obtained from the Microbial Culture Collection at the National Institute for Environmental Studies (NIES Collection, Tsukuba, JAPAN). The NISE 102 cells were cultured in liquid BG-11 medium at $26^{\circ} \mathrm{C}$ and under a fluorescent lump at 3000 Lux, with a light: dark period of 12:12 h for 14 days.

\section{Preparation of the dead cells of CCB-QB1}

The dead cells of CCB-QB1 were prepared based on the method described by Hasyimah et al. (Hasyimah, Furusawa \& Amirul, 2020). To obtain exponential phase cells, the CCB-QB1 cells were cultured in $100 \mathrm{ml}$ of modified $\mathrm{H}-\mathrm{ASWM}$ at $30^{\circ} \mathrm{C}$ for $20 \mathrm{~h}$ with shaking. An optical density at $600 \mathrm{~nm}\left(\mathrm{OD}_{600}\right)$ of cell suspension was measured using a spectrophotometer (UV-1800, Shimadzu, Japan) and adjusted $\mathrm{OD}_{600}=1.0$ with modified H-ASWM broth. The cell suspension was exposed to $3 \mathrm{~W} / \mathrm{m}^{2}$ of UV-A in a laminar flow cabinet (AVC-4D, Esco Technologies Inc, USA) for $10 \mathrm{~min}$, and then the suspension was centrifuged at 3,200 x $g$ for 5 min to harvest cells.

\section{Observation of aggregation formation of the dead cells on NISE 102 cells}

NISE 102 cells in the exponential phase were centrifuged at $1000 \mathrm{x} g$ for $10 \mathrm{~min}$. The cell pellet was suspended into $7 \mathrm{mM} \mathrm{CaCl}_{2}$ solution with $10 \mathrm{mM}$ HEPES buffer ( $\left.\mathrm{pH} 7.6\right)$ and adjusted to $\mathrm{OD}_{680}=0.6\left(4.15 \times 10^{6} \pm 5 \times 10^{4}\right.$ cells $\left./ \mathrm{ml}\right)$. The HEPES buffer was used as a basal buffer for preparing the cell suspension of NISE 102. The wavelength was referred from Sun's report (Sun 
147

148

149

150

151

152

153

et al., 2015). Fifty $\mathrm{mg}$ of the dead cells (wet cells) was added to $10 \mathrm{ml}$ of NISE 102 cell suspension. The suspensions were shaken for $3 \mathrm{~min}$ at $30^{\circ} \mathrm{C}$ with shaking $(100 \mathrm{rpm})$. The aggregates were observed under a light microscope (Olympus BX51, Olympus, Japan).

\section{Effect of incubation time and initial concentration of the dead cells on the removal efficiency.}

One hundred $\mathrm{mg}, 50 \mathrm{mg}$, and $25 \mathrm{mg}$ of the wet dead cells were added to $10 \mathrm{ml}$ aliquots of NISE 102 cells suspension $\left(\mathrm{OD}_{680}=0.6\right)$. The final concentration of the wet dead cells is $10 \mathrm{mg} / \mathrm{ml}$, $5 \mathrm{mg} / \mathrm{ml}, 2.5 \mathrm{mg} / \mathrm{ml}$ and $1 \mathrm{mg} / \mathrm{ml}$ in $10 \mathrm{ml}$ of NISE 102 cells suspension, respectively). The suspensions were shaken at $100 \mathrm{rpm}$ for 3,10 , and $30 \mathrm{~min}$ at $30^{\circ} \mathrm{C}$ in a shaker incubator. The aggregates were settled down at the bottom of the flask for $5 \mathrm{~min}$. After that, $1 \mathrm{ml}$ of the supernatant was carefully removed and transferred to a $1 \mathrm{ml}$ cuvette. The absorbance was measured by a UV spectrophotometer at a wavelength of $680 \mathrm{~nm}$. The removal efficiency was calculated as follows:

$$
\text { Removal efficiency }(\%)=(1-\mathrm{A} / 0.6) \times 100
$$

Where $\mathrm{A}$ is $\mathrm{OD}_{680}$ of samples. 0.6 indicates the initial optical density of NISE 102 cells.

\section{Effect of $\mathrm{CaCl}_{2}$ on the removal efficiency}

Five $\mathrm{mg} / \mathrm{ml}$ of the dead cells (wet cells) was added to NISE 102 cell suspensions $\left(\mathrm{OD}_{680}=\right.$ 0.6) containing $50 \mathrm{mM}, 20 \mathrm{mM}, 5 \mathrm{mM}$, and $1 \mathrm{mM}$ of $\mathrm{CaCl}_{2}$. The suspensions were shaken at 100 $\mathrm{rpm}$ for $3 \mathrm{~min}$ at $30^{\circ} \mathrm{C}$ in a shaker incubator, and the aggregates were settled down at the bottom of the flask for $5 \mathrm{~min}$. The removal efficiency was calculated by the same method described above.

\section{Effect of $\mathrm{FeCl}_{3}$ on the removal efficiency}

One hundred mg/L, $50 \mathrm{mg} / \mathrm{L}, 25 \mathrm{mg} / \mathrm{L}$, and $10 \mathrm{mg} / \mathrm{L}$ of $\mathrm{FeCl}_{3}$ were prepared in NISE 102 cell suspensions adjusted at $\mathrm{OD}_{680}=0.6$ with/without $5 \mathrm{mM} \mathrm{CaCl}_{2}$. The aggregate formation and the removal efficiency were calculated using the procedure described above. Next, to measure the effectiveness of the combination of the dead cells and $\mathrm{FeCl}_{3}$ on the removal efficiency, $10 \mathrm{mg} / \mathrm{L}$ of $\mathrm{FeCl}_{3}$ with $5 \mathrm{mg} / \mathrm{ml}$ of the dead cells (wet cells) was prepared in NISE 102 cell suspensions $\left(\mathrm{OD}_{680}=0.6\right)$ containing $5 \mathrm{mM} \mathrm{CaCl}$. The aggregate formation and calculation of the removal efficiency were conducted using the same procedure described above 
178

179

180

181

182

183

184

185

186

187

192

193

194

195

196

197

198

199

200

201

202

203

204

205

206

207

\section{Scanning electron microscope (SEM) observation of aggregates.}

Fifty $\mathrm{mg}$ of the dead cells were added into $10 \mathrm{ml}$ of the suspension of NISE 102 cells $\left(\mathrm{OD}_{680}\right.$ $=0.6)$ with $\mathrm{CaCl}_{2}$ and mixed at $100 \mathrm{rpm}$ for $3 \mathrm{~min}$. In a sample with $\mathrm{FeCl}_{3}, 10 \mathrm{mg} / \mathrm{L}$ of $\mathrm{FeCl}_{3}$ was prepared in the suspension after mixing both cells for $3 \mathrm{~min}$. The suspension was also mixed at $100 \mathrm{rpm}$ for $3 \mathrm{~min}$ to make samples for SEM observation. The freeze-drying method was used for preparing the SEM samples. The aggregates were transferred to aluminum plates, and the extra water from the samples was carefully removed. The plates were placed on wet filter paper on a petri dish. For fixing the samples, a few drops of $2 \%$ Osmium tetroxide $\left(\mathrm{OsO}_{4}\right)$ were dropped on the filter paper, and the petri dish was immediately closed and left in the fume hood for about $1 \mathrm{~h}$. After that, the samples were frozen in liquid nitrogen for a few seconds and dried using a freezedrying machine (Emitech K750X, Emitech, UK). Finally, the samples were coated with gold and observed by a Leo Supra 50 VP field emission scanning electron microscope (Carl Zeiss, Germany).

\section{Statistical analysis}

All results were represented by the mean \pm standard deviation (SD). All data were subjected to one-way analysis of variance (ANOVA) with Tukey tests to examine significant differences between individual mean values. All statistical tests were carried out using SPSS Version 27.0 (IBM). Differences were considered statistically significant at $P$ values $<0.05$. Independent $t$-test was used to compare the differences between samples with and without $\mathrm{CaCl}_{2}$ (Figure $4 \mathrm{a}$ ) and samples with and without $\mathrm{FeCl}_{3}$ (Figure 4b). The analysis was also conducted by using SPSS Version 27.0.

\section{Results}

\section{Aggregate formation of the dead cells with NISE 102 cells.}

To test the absorption ability of the dead cells of CCB-QB1 against NISE 102 cells, the dead cells of CCB-QB1 and NISE 102 cells were mixed in 10 mM HEPES buffer (pH 7.6) with and without $7 \mathrm{mM} \mathrm{CaCl}_{2}$. Figure 1a showed that both cells formed small aggregates within 3 min incubation period only in the presence of $\mathrm{CaCl}_{2}$. In contrast, the cell aggregates were not observed 
208

in the absence of $\mathrm{CaCl}_{2}$ (Figure 1a). In light microscopic observation, isolated cells of NISE 102 and QB1 were observed in the absence of $\mathrm{CaCl}_{2}$ (Figure 1b, top). On the other hand, NISE 102 cells were surrounded and trapped by many CCB-QB1 cells in the presence of $\mathrm{CaCl}_{2}($ Figure $1 \mathrm{~b}$, bottom), indicating that the dead cells of CCB-QB1 are capable of removing NISE 102 cells.

\section{Effect of incubation time and dosage of the dead cells on removal efficiency}

Generally, incubation time and initial concentration of flocculant are critical factors for forming flocs and removing the target. Hence, the removal rate of NISE 102 cells was measured using $10.0,5.0,2.5$, and $1.0 \mathrm{mg} / \mathrm{ml}$ of the dead cells for each incubation period (3, 10, and $30 \mathrm{~min})$. For $3 \mathrm{~min}$ incubation, the removal efficiency of 10.0 and $5.0 \mathrm{mg} / \mathrm{ml}$ of the dead cells was 76.77 and $75.39 \%$, respectively. The removal rate decreased with decreasing the dosage of the dead cells, such as $71.89(2.5 \mathrm{mg} / \mathrm{ml})$ and $68.06 \%(1.0 \mathrm{mg} / \mathrm{ml})$. Especially, the removal efficiency of the sample with $1.0 \mathrm{mg} / \mathrm{ml}$ was significantly lower than that of the sample with 10.0 and $5.0 \mathrm{mg} / \mathrm{ml}$ $(P<0.05)$. Samples incubated for 10 and $30 \mathrm{~min}$ also exhibited similar tendencies. The samples added of $1.0 \mathrm{mg} / \mathrm{ml}$ of the dead cell exhibited the lowest removal efficiency $(68.06$ and $66.83 \%$, respectively) in both samples. In addition, the removal efficiency of the samples with 10.0 and 5.0 $\mathrm{mg} / \mathrm{ml}$ of the dead cells was similar to among the three different incubation periods. These results indicated that 3 min incubation period was enough to remove NISE 102 cells from the aqueous sample. In addition, the removal efficiency between 10.0 and $5.0 \mathrm{mg} / \mathrm{m}$ samples after $3 \mathrm{~min}$ incubation period was not significantly different $(P>0.05)$. Therefore, the following experiments were conducted with $5.0 \mathrm{mg} / \mathrm{ml}$ of the dead cells for $3 \mathrm{~min}$ incubation period.

\section{Effect of $\mathrm{CaCl}_{2}$ on the removal efficiency.}

To confirm the effect of $\mathrm{CaCl}_{2}$ against the removal of NISE 102 cells, 50, 20, 5, and $1 \mathrm{mM}$ of $\mathrm{CaCl}_{2}$ were added to the suspension of NISE 102 cells. Although we expected that high $\mathrm{CaCl}_{2}$ concentration conditions, $50 \mathrm{mM}$ and $20 \mathrm{mM}$, stimulated robust removal of the cells compared to $5 \mathrm{mM}$ samples, the removal rate of the three samples was quite similar $(75.11,76.44$, and 75.44 $\%$, respectively) $(P>0.05)$ (Figure 3$)$. On the other hand, the sample added of $1 \mathrm{mM}$ of $\mathrm{CaCl}_{2}$ exhibited significantly lower removal efficiency $(30.05 \%)(P<0.05)$ than those of samples containing a higher concentration of $\mathrm{CaCl}_{2}$ (Figure 3). The results showed that the minimum 
238

239

240

241

242

243

244

effective concentration of $\mathrm{CaCl}_{2}$ for removing NISE 102 cells was $5 \mathrm{mM}$, and the concentration was used in the following experiments.

\section{Effect of $\mathrm{CaCl}_{2}$ and $\mathrm{FeCl}_{3}$ on the removal efficiency.}

First, four different concentrations of $\mathrm{FeCl}_{3}, 100,50,25$, and $10 \mathrm{mg} / \mathrm{L}$, were added to the suspension of NISE 102 cells without dead cells of QB1. The removal efficiency of samples with 100 and $50 \mathrm{mg} / \mathrm{L}_{\text {of }} \mathrm{FeCl}_{3}$ exhibited 100 and around $90 \%$ in the absence and presence of $\mathrm{CaCl}_{2}$, respectively (Figure 4a). On the other hand, as shown in Figure 4a, the removal efficiency decreased with decreasing the concentration of $\mathrm{FeCl}_{3}$. The samples with 25 and $10 \mathrm{mg} / \mathrm{L}$ of $\mathrm{FeCl}_{3}$ removed 61.67 and $40.23 \%$ of the cells without $\mathrm{CaCl}_{2}$ (Figure 4a). Interestingly, the removal efficiency increased with adding the $5 \mathrm{mM} \mathrm{CaCl}_{2}$ in the samples with 25 and $10 \mathrm{mg} / \mathrm{L}$ of $\mathrm{FeCl}_{3}$ as 76.44 and $57.61 \%$, respectively (Figure 4a). Especially, the removal rate with $10 \mathrm{mg} / \mathrm{L} \mathrm{of} \mathrm{FeCl}_{3}$ with $\mathrm{CaCl}_{2}$ was 1.43 times higher than that without $\mathrm{CaCl}_{2}(\mathrm{P}<0.05)$. This result showed that the removal efficiency with $10 \mathrm{mg} / \mathrm{L}$ of $\mathrm{FeCl}_{3}$ was improved by adding $5 \mathrm{mM} \mathrm{CaCl}_{2}$.

In Figure 4b, the removal efficiency of $10 \mathrm{mg} / \mathrm{L} \mathrm{FeCl}_{3}$ with the dead cell on NISE 102 cells was tested. The removal efficiency of $\mathrm{FeCl}_{3}$ with the dead cell was $70.28 \%$. Expectedly, the removal efficiency was significantly improved from $70.28 \%$ to $84.17 \%$ by adding $5 \mathrm{mM} \mathrm{CaCl}_{2}$ $(P<0.05)$ (Figure. 4b).

\section{SEM observation of cell aggregates}

The aggregates were observed under SEM to investigate how dead cells formed the aggregates with NISW 102 cells. In the sample without $\mathrm{FeCl}_{3}$, big aggregates were observed (Figure 5a), and many NISE 102 cells were trapped in the aggregates (Figure 5b). The dead cells that possessed filamentous structures got entangled in each filamentous cell. The dead cells tightly attached to the surface of NISE 102 cells, and the entangled cells captured NISE 102 cells (Figure $5 \mathrm{c}$ and $\mathrm{f}$ ). Big aggregates were also observed in the sample with $\mathrm{FeCl}_{3}$ (Figure 5d). Many NISE 102 cells were also trapped in the aggregates as well as the sample without $\mathrm{FeCl}_{3}$ (Figure 5e). Compared to the sample without $\mathrm{FeCl}_{3}$, the cells were packed more tightly in the aggregates (Figure 5f). 
268

\section{Discussion}

In this study, we tried to apply the dead cells of CCB-QB1 for removing harmful algae, $M$. aeruginosa. Our previous investigations demonstrated that CCB-QB1 cells aggregated in the presence of $7 \mathrm{mM} \mathrm{CaCl}_{2}$ (Furusawa, Hartzell \& Navaratnam, 2015), and the dead cells of CCBQB1 formed aggregates with kaolin clay particles in the same condition (Hasyimah, Furusawa \& Amirul, 2020). In keeping with these data, we expected that the dead cells of CCB-QB1 could also form aggregates and precipitate on $M$. aeruginosa in the presence of $\mathrm{CaCl}_{2}$. To confirm the hypothesis, the dead cells of CCB-QB1 and NISE 102 cells were mixed in the buffer with or without $\mathrm{CaCl}_{2}$. As shown in Figure 1a, although no cell aggregates were observed in the absence of $\mathrm{CaCl}_{2}$, the dead cells could make aggregates with NISE 102 cells in the presence of $\mathrm{CaCl}_{2}$. In addition, the removal efficiency of NISE 102 cells decreased under low $\mathrm{CaCl}_{2}$ concentration (1 $\mathrm{mM}$ ) (Figure 3), indicating that $\mathrm{CaCl}_{2}$ is crucial for removing NISE 102 cells. Several investigators described that the cell surface of $M$. aeruginosa is negatively charged in water (Hadjoudja, Deluchat \& Baudu, 2010; Shi et al., 2016). Generally, the net charge of the bacterial cell surface is also negative (Corpe, 1970; Li et al., 2019; Pajerski et al., 2019). Our previous investigations also indicated that the cell surface of CCB-QB was negatively charged (Furusawa, Hartzell \& Navaratnam, 2015). However, the dead cells of CCB-QB1 could adsorb negatively charged materials, such as kaolin clay particles, in the presence of $\mathrm{CaCl}_{2}$ because $\mathrm{Ca}^{2+}$ might help neutralize the electrical forces (Hasyimah, Furusawa \& Amirul, 2020). Sato and colleagues described that the addition of EPS produced by cyanobacteria and $1000 \mathrm{mg} / \mathrm{L}$ of calcium (approximately $9 \mathrm{mM}$ ) was stimulated the colonization of M. aeruginosa cells (Sato et al., 2017). The addition of EPS and calcium decreased the zeta potential of M. aeruginosa cells and promoted its colonization. However, when only EPS was added, the zeta potential hardly decreased (Sato et al., 2017), resuling in inhibiting the colonization. These investigations revealed that $\mathrm{Ca}^{2+}$ plays an important role in neutralizing the charge of $M$. aeruginosa cells. Thus, it is expected that the negative charge of NISE 102 and the dead cells might also be neutralized by $\mathrm{Ca}^{2+}$, and the neutralization may eliminate repulsive electron forces between the dead cells and NISE 102 cells. As a result, $\mathrm{Ca}^{2+}$ might facilitate the biosorption of the dead cells against NISE 102 cells.

$\mathrm{FeCl}_{3}$ was used as a flocculant for removing $M$. aeruginosa cells from aqueous samples (Li et al., 2015; Hao et al., 2016; Gao, Shimizu \& Xue, 2012). In this study, we also performed to use $\mathrm{FeCl}_{3}$ as a coagulant. Figure 4a showed that the removal efficiency of NISE 102 cells by a low 
concentration of $\mathrm{FeCl}_{3}$ was enhanced by adding $\mathrm{CaCl}_{2}$. Figure $5 \mathrm{f}$ also showed that the dead cells were more tightly aggregated in the presence of $\mathrm{CaCl}_{2}$ and $\mathrm{FeCl}_{3}$. The absorption of $\mathrm{Fe}(\mathrm{OH})_{3}$ generated from $\mathrm{FeCl}_{3}$ by organic matters could explain this result (Amuda \& Amoo, 2007). Besides that, Liu et al. reported that $\mathrm{Ca}^{2+}$ increased the zeta potential of $\mathrm{Fe}(\mathrm{OH})_{3}$ and facilitated $\mathrm{Fe}(\mathrm{OH})_{3}$ floc aggregation (Liu et al., 2007). These investigations indicated that the increase of zeta potential and the promotion of floc aggregation by $\mathrm{Fe}(\mathrm{OH})_{3}$ via the addition of $\mathrm{Ca}^{2+}$ enhance the removal of NISE 102 cells. Figure 4 a demonstrated that a high removal efficiency $(>90 \%)$ of NISE 102 cells was observed when the dosage of $\mathrm{FeCl}_{3}$ was more than $50 \mathrm{mg} / \mathrm{L}$. Li et al. also described that the addition of $50 \mathrm{mg} / \mathrm{L}$ of $\mathrm{FeCl}_{3}$ exhibited almost the maximum removal efficiency on $M$. aeruginosa cells (Li et al., 2015). Hao and colleagues also showed that M. aeruginosa cells could aggregate when the dosage of $\mathrm{FeCl}_{3}$ was $175 \mathrm{mg} / \mathrm{L}$ (Hao et al., 2016). Thus, the addition of a high dosage of $\mathrm{FeCl}_{3}$ was required to remove M. aeruginosa cells. Figure $4 \mathrm{~b}$ demonstrated that the addition of only $10 \mathrm{mg} / 1$ of $\mathrm{FeCl}_{3}$ significantly improved the removal efficiency. These results also revealed that the combination of the dead cells and $\mathrm{CaCl}_{2}$ could reduce the dosage of $\mathrm{FeCl}_{3}$ for removing M. aeruginosa cells.

Sun and colleagues reported that maximum removal efficiency by bioflocculants from $B$. amyloliquefaciens strain DT and P. aeruginosa strain ZJU1 was reached within $10 \mathrm{~min}$. (Sun et al., 2015a; Sun et al., 2015b). The bioflocculant from Klebsiella pneumonia took 1.6 hours for floc formation with $M$. aeruginosa cells (Xu et al., 2016). In contrast, in this study, the maximum removal efficiency by the dead cells was reached within $3 \mathrm{~min}$ (Figure 2). This iresult revealed that the dead cells were able to quickly remove $M$. aeruginosa cells compared to other bioflocculants based on EPS from microorganisms. Another advantage of the usage of the dead cells is that the preparation process of the dead cells is simpler than that of other bioflocculants based on EPS from microorganisms. Generally, bioflocculant-producing bacteria were cultured for 2-3 days in a nutrient-rich broth. For instance, several types of saccharides $(5.0 \mathrm{~g} / \mathrm{L}$ sucrose, $2.0 \mathrm{~g} / \mathrm{L}$ glucose, and $2.0 \mathrm{~g} / \mathrm{L}$ maltose) were added to the culture broth to produce a bioflocculant from $P$. aeruginosa ZJU1 (Sun et al., 2015b). In addition, two volumes of cold ethanol were required to recover the bioflocculant released into the culture supernatant. Finally, the crude bioflocculant was centrifuged to harvest and dried by heat treatment or freeze-drying. In contrast, the CCB-QB1 cells were cultured in a seawater medium without adding any carbon sources. The incubation period to obtain the cells was $24 \mathrm{~h}$ (Hasyimah, Furusawa \& Amirul, 2020). After 10 min UV treatment, the dead cells were able to use as a bioflocculant (Hasyimah, Furusawa \& 
Amirul, 2020). Thus, the preparation procedure of the dead cells was quite simple in comparison with the other bioflocculants, suggesting that the production cost of the dead cells might be cheaper than that of known bioflocculants consisted of EPS from microorganisms.

It was reported that some plant-based natural coagulants also successfully removed $M$. aeruginosa cells. For example, protein-based coagulant extracted using a salt solution $(1 \mathrm{M} \mathrm{NaCl}$ or $1 \mathrm{M} \mathrm{CaCl}_{2}$ ) from Moringa oleifera seeds exhibited a high removal rate (78.9 \%) on $M$. aeruginosa cells (Carvalho et al., 2016). Moreti and colleagues also reported that a saline extract from M. oleifera seeds could remove M. aeruginosa cells effectively (de Oliveira Ruiz Moreti et al., 2019). Interestingly, the extract could adsorb and remove microcystin-LR (de Oliveira Ruiz Moreti et al., 2019). The preparation procedure of the extract using saline solution was more straightforward than that of bioflocculants consisted of EPS. However, many pretreatment processes, such as dehusking, powdering, and drying, were required. Of course, the large agricultural land and long cultivating period to obtain seeds are necessary for culturing M. oleifera. In contrast, the biomass production of CCB-QB1 is faster and easier than the plant.

\section{Conclusion}

In this study, the dead cells of a marine filamentous bacteria, Aureispira sp. CCB-QB1, was used as a bioflocculant for removing a harmful freshwater microalga, M. aeruginosa. The dead cells were removed about $75 \%$ of $M$. aeruginosa cells with 3 min incubation in the presence of $\mathrm{CaCl}_{2}$. The optimization of $\mathrm{CaCl}_{2}$ concentration for removing the $M$. aeruginos a cells showed that the optimal concentration of $\mathrm{CaCl}_{2}$ was $5 \mathrm{mM}$. The removal efficiency by inorganic flocculant, $\mathrm{FeCl}_{3}$, was improved by the addition of $\mathrm{CaCl}_{2}$. Besides that, the combination of the dead cells and $\mathrm{CaCl}_{2}$ could reduce the dosage of $\mathrm{FeCl}_{3}$ for removing M. aeruginosa cells. These results indicated that the dead cells have the potential for a novel and alternative bioflocculant.

\section{Acknowledgment}


We are thankful to the Microscopy Unit in Universiti Sains Malaysia for SEM observation.

363

364

365

366

367

\section{References}

Amuda, O. S.; Amoo, I. A. Coagulation/flocculation process and sludge conditioning in beverage industrial wastewater treatment. J. Hazard. Mater. 2007, 141, 778-783.

Azevedo, S.M.F.O.; Carmichael, W.W.; Jochimsen, E.M.; Rinehart, K.L.; Lau, S.; Shaw, G. R.; Eaglesham, G. K. Human intoxication by microcystins during renal dialysis treatment in Caruaru-Brazil. Toxicology 2002, 181, 441-446.

Azzam, A. M.; Tawfik, A. Removal of heavy metals using bacterial bio-flocculants of Bacillus sp. and Pseudomonas sp. J. Environ. Eng. Landsc. Manag. 2015, 23 (4), 288-294.

Briand, J.F.; Jacquet, S.; Bernard, C.; Health hazards for terrestrial vertebrates from toxic cyanobacteria in surface water ecosystems. Vet. Res. 2003, 34, 361-377.

Cai, Q.; Song, K.; Tian, C.; Wu, X.; Li, Y.; Huang, Y.; Wang, C.; Xiao, B. Harvesting of Microcystis from waterbody by flocculation and filtration: the essential role of extracellular organic matters. J. Water Process Eng. 2021, 41, 102053.

Carvalho, M. S.; Alves, B. R. R.; Silva, M. F.; Bergamasco, R.; Coral, L. A.; Bassetti, F. J. $\mathrm{CaCl}_{2}$ applied to the extraction of Moringa oleifera seeds and the ues for Microcystis aeruginosa removal. Chem, Eng, Technol. 2016, 304, 469-475.

Corpe, W. A. Attachment of Marine Bacteria to Solid Surfaces; In Adhesion in biological systems, Manly, R., Ed.; Academic Press, New York, USA, 1970; 73-87.

Dearfield, K. L.; Abernathy, C. O.; Ottley, M. S.; Brantner, J. H.; Hayes, P. F. Acrylamide: its metabolism, developmental and reproductive effects, genotoxicity, and carcinogenicity. Mutat. Res. Genet. Toxicol. 1988, 195, 45-77. 
Dearfield, K. L.; Douglas, G. R.; Ehling, U. H.; Moore, M. M.; Sega, G. A.; Brusick, D. J. Acrylamide: Acrylamide: a review of its genotoxicity and an assessment of heritable genetic risk. Mutat. Res. Mol. Mech. Mutagen. 1995, 330, 71-99.

Deng, S. B.; Bai, R. B.; Hu, X. M.; Luo, Q. Characteristics of a bioflocculant produced by Bacillus mucilaginosus and its use in starch wastewater treatment. Appl. Microbiol. Biotechnol. 2003, 60, 588-593. https://doi.org/10.1007/s00253-002-1159-5.

De Oliveira Ruiz Moreti, L.; Takaoka, A. B.; Marquettotti, A.; Vieira, S.; Mantovani, D.; Bergamasco, R. The use of Moringa oleifera seeds and their fractionated proteins for Microcystis aeruginosa and microcystin-LR removal from water. Can. J. Chem. Eng. 2019, 97, 1307-1316.

Fast, S. A.; Kokabian, B.; Gude, V. G. Chitosan enhanced coagulation of algal turbid waters-Comparison between rapid mix and ultrasound coagulation methods. Chem. Eng. J. 2014, 244, 403-410.

Flaten, T. P. Aluminium as a risk factor in Alzheimer's disease, with emphasis on drinking water. Brain Res. Bull. 2001, 55, 187-196.

Furusawa, G.; Hartzell, P. L.; Navaratnam, V. Calcium is required for ixotrophy of Aureispira sp. CCB-QB1. Microbiol. (United Kingdom) 2015, 161, 1933-1941. https://doi.org/10.1099/mic.0.000158.

Gao, Y. U.; Shimizu, K.; Xue, Q. Inhibition of growth and microcystins production on Microcystis aeruginosa by electrolytic method. Jpn. J. Water Treat. Biol. 2012, 48, 125132.Hadjoudja, S.; Deluchat, V.; Baudu, M. Cell surface characterisation of Microcystis aeruginosa and Chlorella vulgaris. J. Colloid Interface Sci. 2010, 342 (2), 293-299.

Hamilton, D.P.; Salmaso, N.; Paerl, H.W. Mitigating harmful cyanobacterial blooms: strategies for control of nitrogen and phosphorus loads. Aquat. Ecol. 2016, 50, 351-366.

Hao, J.; Lian, B.; Zhou, R.; Liu, H.; Shi, L.; Liu, C. Microbial flocculant combined ferric trichloride facilitates floating aggregation of Microcystis aeruginosa for efficient removal. Desalin. Water Treat. 2016, 57 (43), 20483-20493. 
Hasyimah, N. A. R.; Furusawa, G.; Amirul, A. A. Biosorption of a dye and heavy metals using dead cells of filamentous bacterium, Aureispira sp. CCB-QB 1. Int. J. Environ. Sci. Technol. 2020, 1-10.

He, N.; Li, Y.; Chen, J. Production of a novel polygalacturonic acid bioflocculant REA-11 by Corynebacterium glutamicum. Bioresour. Technol. 2004, 94, 99-105. https://doi.org/10.1016/j.biortech.2003.11.013.

Katırcıŏlu, H.; Akin, B. S.; Atici, T. Microalgal toxin (s): characteristics and importance. African J. Biotechnol. 2004, 3, 667-674.

Kumar, V.; Othman, N.; Asharuddin, S. Applications of natural coagulants to treat wastewater - a review. MATEC Web Conf. 2017, 103, 06016. http://doi:10.1051/matecconf/201710306016 Kurenkov, V. F.; Hartan, H.-G.; Lobanov, F. I. Application of polyacrylamide flocculants for water treatment. Chem. Comput. Simul. Butl. Commun 2002, 3, 31-40. Li, O.; Lu, C.; Liu, A.; Zhu, L.; Wang, P. M.; Qian, C. D.; Jiang, X. H.; Wu, X. C. Optimization and characterization of polysaccharide-based bioflocculant produced by Paenibacillus elgii B69 and its application in wastewater treatment. Bioresour. Technol. 2013, 134, 87-93. https://doi.org/10.1016/j.biortech.2013.02.013.

Li, Z.; Ma, J.; Ruan, J.; Zhuang, X. Using positively charged magnetic nanoparticles to capture bacteria at ultralow concentration. Nanoscale Res. Lett. 2019, 14, 1-8.

Li, X.; Pei, H.; Hu, W.; Meng, P.; Sun, F.; Ma, G.; Xu, X.; Li, Y. The fate of Microcystis aeruginosa cells during the ferric chloride coagulation and flocs storage processes. Environ. Technol. 2015, 36 (7), 920-928.

Liu, W.; Hao, Y.; Jiang, J.; Zhu, A.; Zhu, J.; Dong, Z. Production of a bioflocculant from Pseudomonas veronii L918 using the hydrolyzate of peanut hull and its application in the treatment of ash-flushing wastewater generated from coal fired power plant. Bioresour. Technol. 2016, 218, 318-325. 
Liu, R.; Li, X.; Xia, S.; Yang, Y.; Wu, W.; Li, G. Calcium-enhanced ferric hydroxide co-precipitation of arsenic in the presence of silicate. Water Environ. Res. 2007, 79, 2260 2264

Ma, C.; Hu, W.; Pei, H.; Xu, H.; Pei, R. Enhancing integrated removal of Microcystis aeruginosa and adsorption of microcystins using chitosan-aluminum chloride combined coagulants: effect of chemical dosing orders and coagulation mechanisms. Colloids Surfaces A Physicochem. Eng. Asp. 2016, 490, 258-267.

Pajerski, W.; Ochonska, D.; Brzychczy-Wloch, M.; Indyka, P.; Jarosz, M.; Golda-Cepa, M.; Sojka, Z.; Kotarba, A. Attachment efficiency of gold nanoparticles by Gram-positive and Gram-negative bacterial strains governed by surface charges. J. Nanoparticle Res. 2019, 21, $1-12$.

Park, Y. H.; Kim, S.; Kim, H. S.; Park, C.; Choi, Y.-E. Adsorption strategy for removal of harmful cyanobacterial species Microcystis aeruginosa using chitosan fiber. Sustainability 2020, 12, 4587.

Pugazhendhi, A.; Shobana, S.; Bakonyi, P.; Nemestóthy, N.; Xia, A.; Kumar, G. A review on chemical mechanism of microalgae flocculation via polymers. Biotechnol. Reports 2019, $21, \mathrm{e} 00302$.

Salehizadeh, H.; Shojaosadati, S. A. Extracellular biopolymeric flocculants: recent trends and biotechnological importance. Biotechnol. Adv. 2001, 19 (5), 371-385.

Sato, M.; Amano, Y.; Machida, M.; Imazeki, F. Colony formation of highly dispersed Microcystis aeruginosa by controlling extracellular polysaccharides and calcium ion concentrations in aquatic solution. Limnology 2017, 18 (1), 111-119.

Shi, W.; Tan, W.; Wang, L.; Pan, G. Removal of Microcystis aeruginosa using cationic starch modified soils. Water Res. 2016, 97, 19-25

Sun, F.; Pei, H.-Y.; Hu, W.-R.; Ma, C.-X. The lysis of Microcystis aeruginosa in $\mathrm{AlCl}_{3}$ coagulation and sedimentation processes. Chem. Eng. J. 2012, 193, 196-202. 
Sun, P.; Hui, C.; Bai, N.; Yang, S.; Wan, L.; Zhang, Q.; Zhao, Y. Revealing the characteristics of a novel bioflocculant and its flocculation performance in Microcystis aeruginosa removal. Sci. Rep. 2015, 5 (1), 1-12.

Sun, P.-F.; Lin, H.; Wang, G.; Lu, L.-L.; Zhao, Y.-H. Preparation of a new-style composite containing a key bioflocculant produced by Pseudomonas aeruginosa ZJU1 and its flocculating effect on harmful algal blooms. J. Hazard. Mater. 2015, 284, 215-221.

Visser, P. M.; Verspagen, J. M. H.; Sandrini, G.; Stal, L. J.; Matthijs, H. C. P.; Davis, T. W.; Paerl, H. W.; Huisman, J. How rising CO2 and global warming may stimulate harmful cyanobacterial blooms. Harmful Algae 2016, 54, 145-159.

Wang, S. G.; Gong, W. X.; Liu, X. W.; Tian, L.; Yue, Q. Y.; Gao, B. Y. Production of a novel bioflocculant by culture of Klebsiella mobilis using dairy wastewater. Biochem. Eng. J. 2007, 36 (2), 81-86. https://doi.org/10.1016/j.bej.2007.02.003.

Xia, S.; Zhang, Z.; Wang, X.; Yang, A.; Chen, L.; Zhao, J.; Leonard, D.; Jaffrezic-Renault, N. Production and characterization of a bioflocculant by Proteus mirabilis TJ-1. Bioresour. Technol. 2008, 99 (14), 6520-6527. https://doi.org/10.1007/978-3-319-46601-9_29.

Xu, L.; Huo, M.; Yang, W.; Zhou, D.; Huo, H. Klebsiella pneumoniae metabolites enhance Microcystis aeruginosa biomass flocculation. Chem. Ecol. 2016, 32 (9), 858-871.

Zhang, Y.; Tian, J.; Nan, J.; Gao, S.; Liang, H.; Wang, M.; Li, G. Effect of PAC addition on immersed ultrafiltration for the treatment of algal-rich water. J. Hazard. Mater. 2011, $186,1415-1424$.

Zhang, D.; Ye, Q.; Zhang, F.; Shao, X.; Fan, Y.; Zhu, X.; Li, Y.; Yao, L.; Tian, Y.; Zheng, T. F Flocculating properties and potential of Halobacillus sp. strain H9 for the mitigation of Microcystis aeruginosa blooms. Chemosphere 2019, 218, 138-146. 
Zheng, Y.; Ye, Z. L.; Fang, X. L.; Li, Y. H.; Cai, W. M. Production and characteristics of a

492 bioflocculant produced by Bacillus sp. F19. Bioresour. Technol. 2008, 99, 7686-7691.

493 https://doi.org/10.1016/j.biortech.2008.01.068. 


\section{Figure 1}

Figure 1

Figure 1. Observation of cell aggregates consisted of the dead cells and NISE 102 cells in the presence of $7 \mathrm{mM} \mathrm{CaCl}_{2}$. (a) Aggregation formation by the dead cells with NISE 102 cells. Top is the sample without $\mathrm{CaCl}_{2}$. Bottom is the sample with $\mathrm{CaCl}_{2}$. (b) Light microscopic observation of both the dead cells and NISE 102 cells (Top) and the inside of the aggregate (Bottom) (x1000). Top is the sample without $\mathrm{CaCl}_{2}$. Bottom is the sample with $\mathrm{CaCl}_{2}$. The scale bar (a) $1 \mathrm{~cm}$, (b) $20 \mu \mathrm{m}$.

(a)
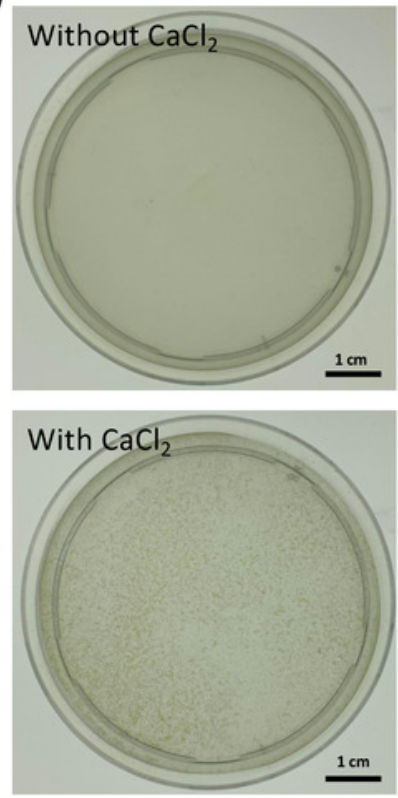

(b)
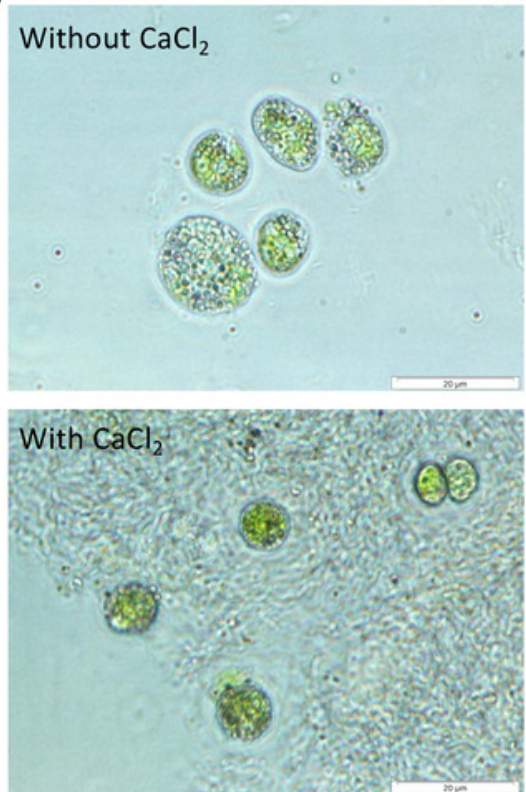

\section{Without $\mathrm{CaCl}_{2}$}

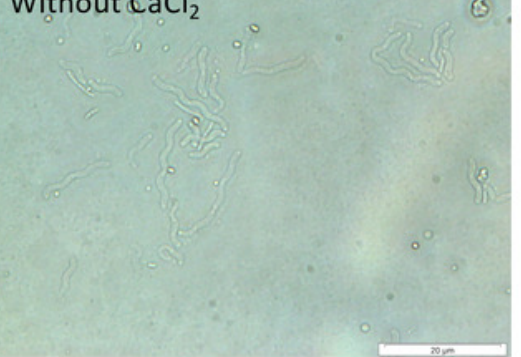




\section{Figure 2}

Figure 2

Figure 2. Effect of incubation time and dosage of the dead cells on removal efficiency of NISE 102 cells. 1.0, 2.5, 5.0, and $10.0 \mathrm{mg} / \mathrm{ml}$ of the dead cells (wet cell) with $7 \mathrm{mM} \mathrm{CaCl}{ }_{2}$ were mixed with NISE 102 cells for 3, 10, and 30 min with shaking (100 rpm). Different letter indicates a significant difference (One-way ANOVA and Tukey's analysis, $P<0.05$ ). 


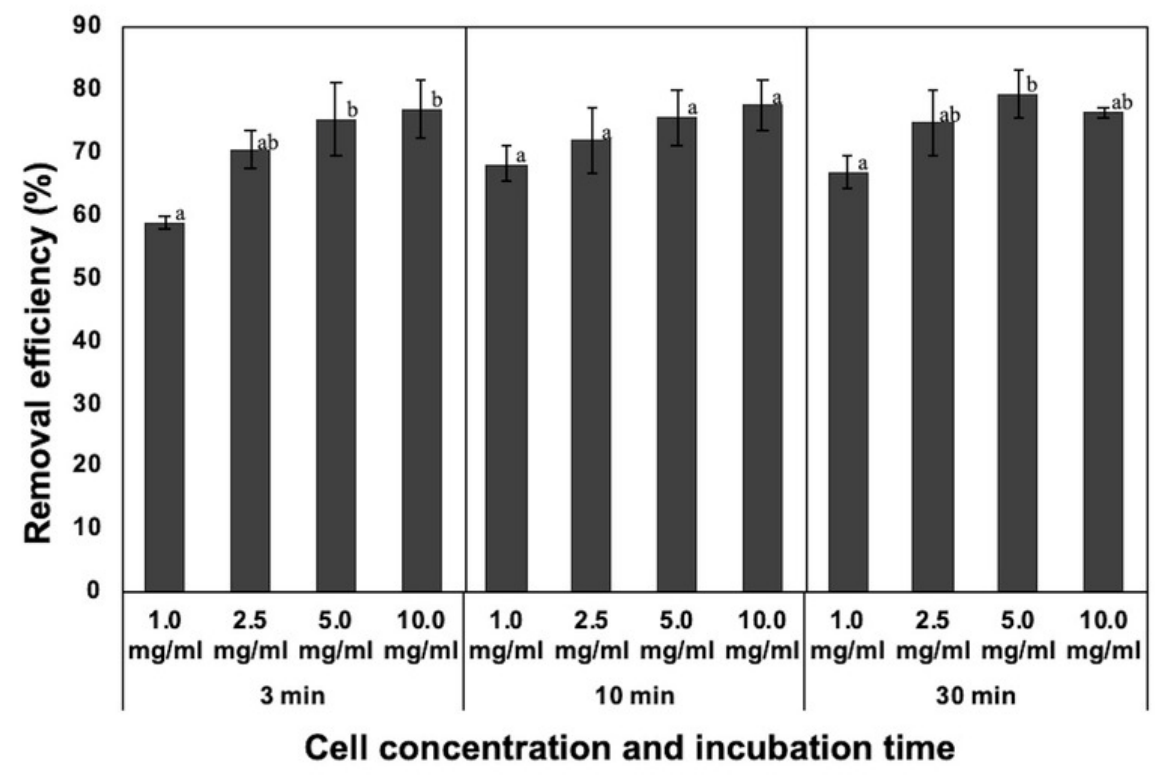




\section{Figure 3}

Figure 3

Figure 3. Effect of calcium ion on the removal efficiency of NISE 102 cells. 1, 5, 20, $50 \mathrm{mM}$ of $\mathrm{CaCl}_{2}$ were added into NISE 102 cell suspension with $5.0 \mathrm{mg} / \mathrm{ml}$ of the dead cell. The suspension was mixed for $3 \mathrm{~min}$. Different letter indicates a significant difference (One-way ANOVA and Tukey's analysis, $P<0.05)$. 


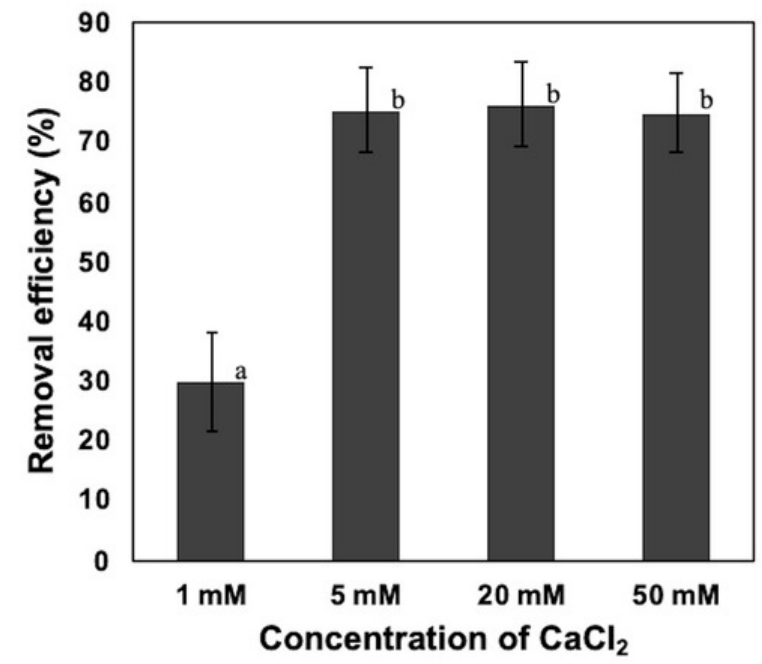


Figure 4

Figure 4

Figure 4.Effect of $\mathrm{CaCl}_{2}$ and $\mathrm{FeCl}_{3}$ on the removal efficiency of NISE 102 cells. (a) The removal efficiency of NISE 102 cells on different concentration of $\mathrm{FeCl}_{3}(10,25,50,100$ $\mathrm{mg} / \mathrm{ml}$ ) without the dead cells. Blue bars indicate samples without $\mathrm{CaCl}_{2}$, Orange bars indicate samples with $\mathrm{CaCl}_{2}$. (b) The removal efficiency of NISE 102 cells with the dead cells in the presence of $\mathrm{FeCl}_{3}(10 \mathrm{mg} / \mathrm{ml})$ with and without $7 \mathrm{mM} \mathrm{CaCl}$. Asterisks in (a) and (b) indicate the significant difference (Independent t-test, $P<0.05$ ). 
(a)

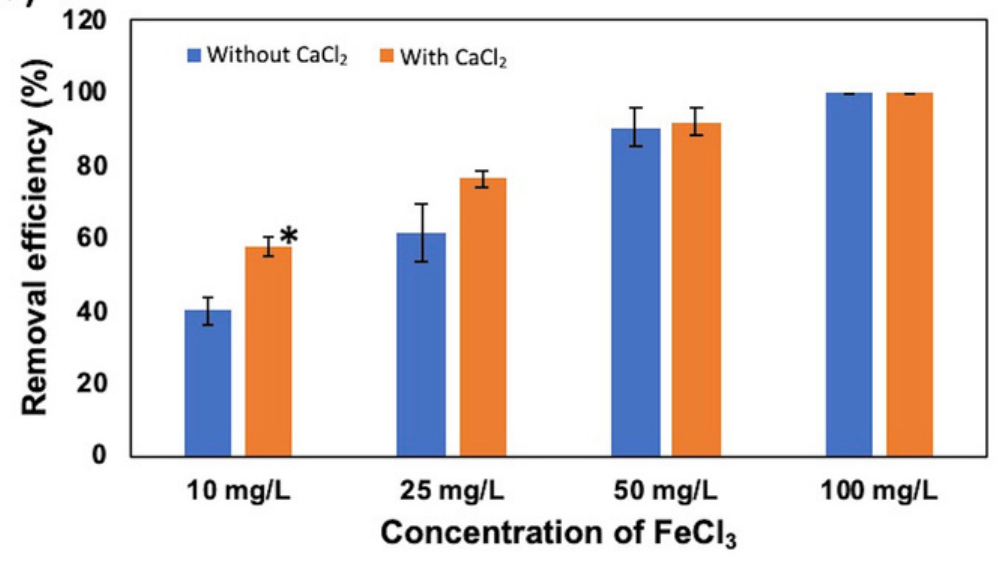

(b)

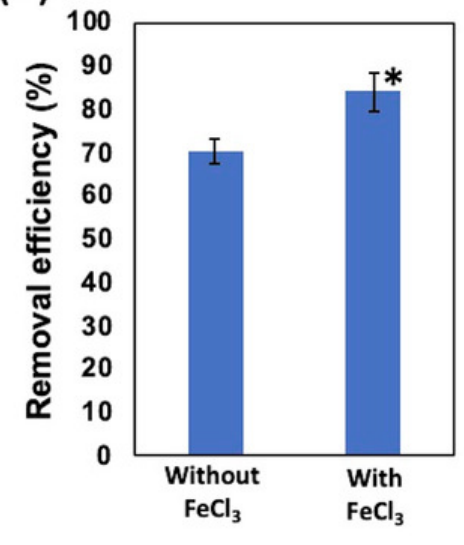


Figure 5

Figure 5

Figure 5. Scanning electron micrographs of the aggregates consisted of the dead cells and NISE 102 cells. (a), (b), and (c); Samples without $\mathrm{FeCl}_{3}$. (d), (e), and (f); Samples with $\mathrm{FeCl}_{3}$. The scale bars a; $100 \mu \mathrm{m}(100 \mathrm{X}), \mathrm{b} ; 20 \mu \mathrm{m},(400 \mathrm{X})$ c; $2 \mu \mathrm{m}(1,500 \mathrm{X})$, d; e; $2 \mu \mathrm{m}(4,000 \mathrm{X})$, $100 \mu \mathrm{m}(100 \mathrm{X}), \mathrm{f} ; 10 \mu \mathrm{m}(500 \mathrm{X}), \mathrm{g} ; 2 \mu \mathrm{m}(1,500 \mathrm{X})$. 


\section{Without $\mathrm{FeCl}_{3}$}

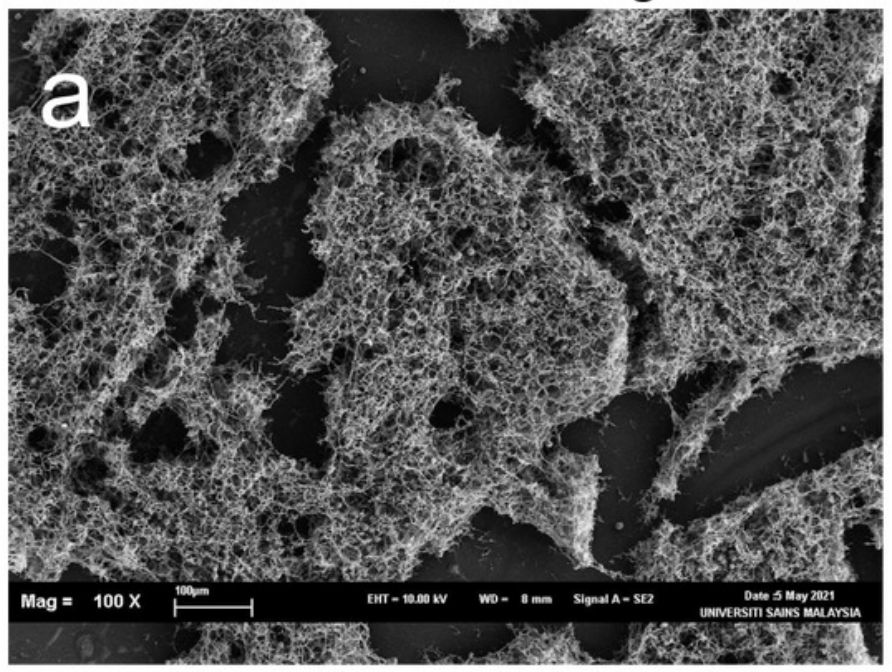

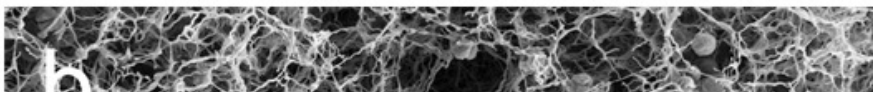
23 3.

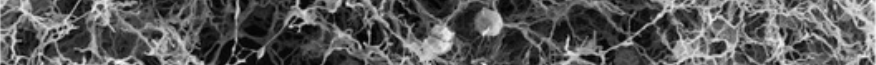

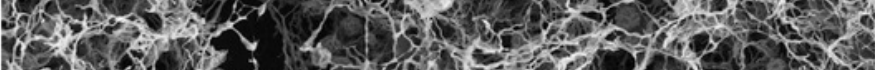

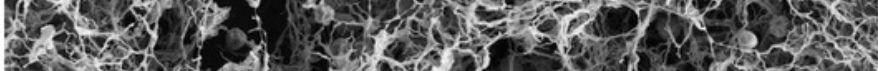

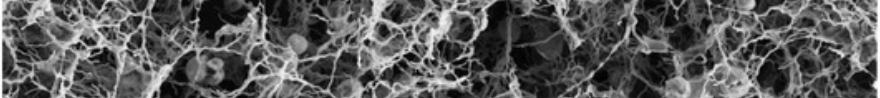

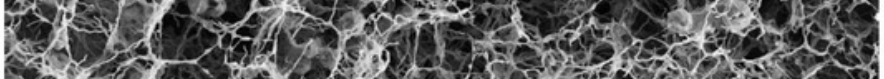

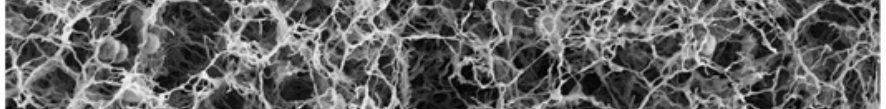
W.

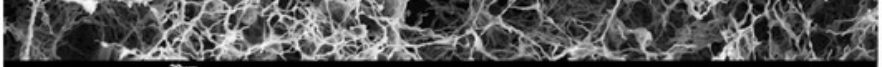

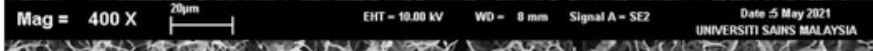

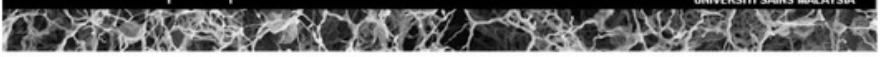

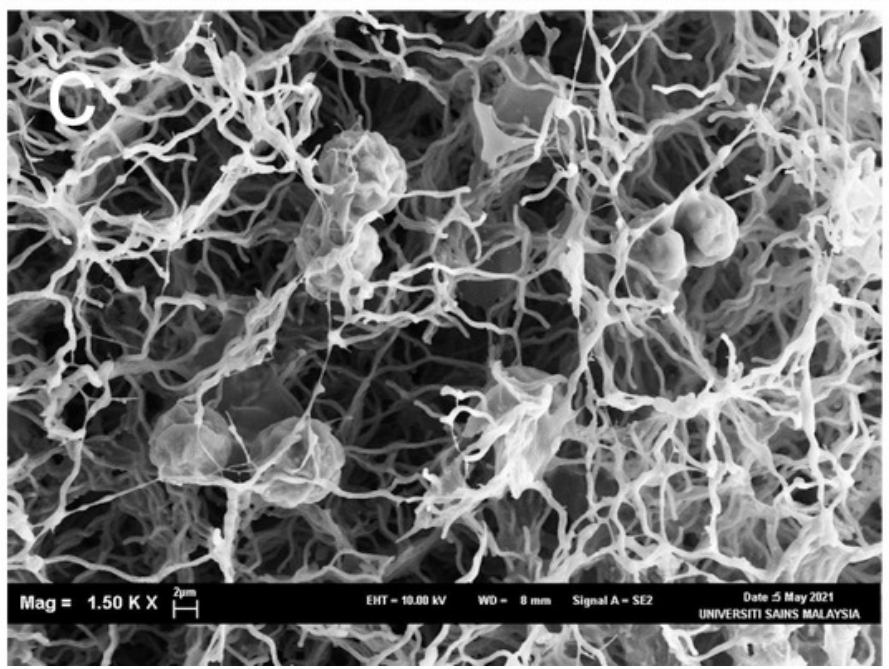

\section{With $\mathrm{FeCl}_{3}$}
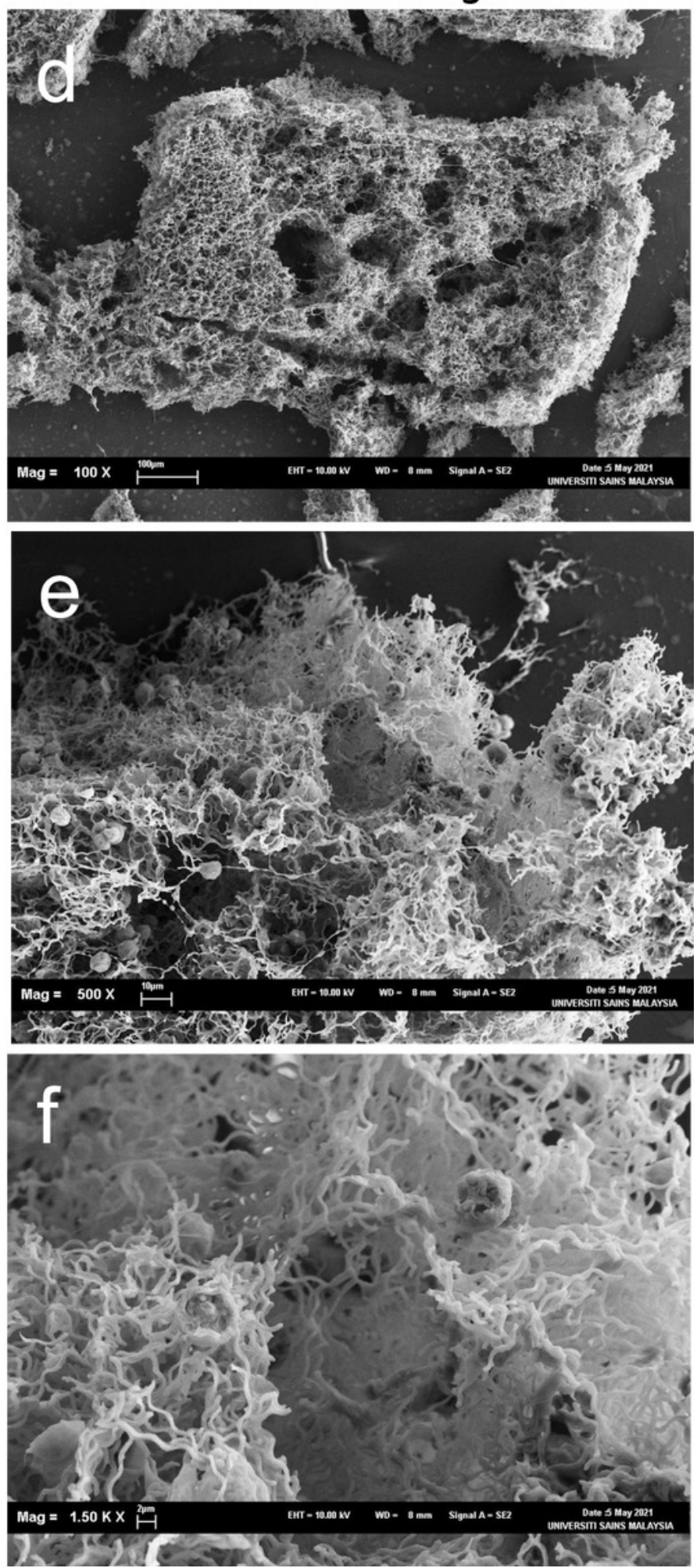